Turkish Journal of Geriatrics

DOI: $10.31086 /$ tigeri.2019.114

2019; 22(3): 368-375

- Hayriye AKTAŞ DINÇER ${ }^{1}$ D - Didem GÖKÇAY ${ }^{2}$ (D)

\section{TIME BISECTION ABILITY IN SUPRA-SECONDS IS PRESERVED DURING HEALTHY AGING}

\section{A BStRAct}

Introduction: Interval timing requires cognitive resources such as attention, longterm memory, and working memory. Unfortunately, these functions deteriorate with aging. Changes in time perception are reported in healthy aging, in addition to several different neuropsychiatric disorders. Although age-related changes in time perception have been amply described in the literature, the actual underlying mechanisms remain controversial.

Materials and Method: This study included a total of 33 young (mean age $=23.31$ years) and 33 old (mean age $=67.63$ years) individuals who performed a time bisection task with a range of 1.25-2.5 seconds. The experimental design was strictly controlled to minimize the effects of age-related declines in cognitive functions. An additional psychometric measurement related to the subjective passage of time was also assessed.

Results: A Mann-Whitney U test was conducted with the bisection point, Weber ratio, and difference limen as the dependent variables. The young and old participants showed similar time bisection performances $(p \geq 0.05)$. However, the verbal expression of the subjects indicated that time generally passes faster for old individuals whereas old participants expected the next hour to pass slower for them than did their younger counterparts $(p \leq 0.05)$.

Conclusion: It was demonstrated that the perception of time is preserved with aging in the supra-second range when cognitive demands are minimized by reducing task complexity.

Keywords: Aging; Time perception
CORRESPONDANCE

Hayriye AKTAŞ DINÇER

Middle East Technical University, Biomedical

Engineering, Ankara, Turkey.

Phone: +903122107872

Mobile: +905415874071

e-mail: aktashayriye@gmail.com

Received: 29/03/2019

Accepted: 19/08/2019

1Middle East Technical University, Biomedical Engineering, Ankara, Turkey.

Middle East Technical University, Informatics Institute, Health Informatics, Ankara, Turkey.
ARASTIRMA

\section{SANIYE ÜSTÜNDE SÜRE AYRIŞTIRMA YETENEĞi SAĞLIKLI YAŞLANMADA KORUNMAKTADIR}

\section{$\ddot{O}_{z}$}

Giriş: Aralık zamanlama, dikkat, uzun süreli bellek ve çalışma belleği gibi bilişsel kaynakların kullanılmasını gerektirmektedir. Maalesef, bu işlevleryaşlanmayla birlikte bozulmaktadır. Zaman algısındaki değişiklikler sağlıklı yaşlanmanın yanı sıra çeşitli nöropsikiyatrik bozukluklarda da görülmüştür. Her ne kadar zaman algısındaki yaşa bağlı değişiklikler literatürde fazlasıyla bildirilmiş olsa da, asıl altta yatan mekanizmalar tartışmalıdır.

Gereç ve Yöntem: 33 genç (ortalama yaş $=23,31$ ) ve 33 yaşlı (ortalama yaş $=67,63$ ) gönüllü 1,25-2,5 saniye aralığında bir süre ayrıştırma görevi yapmak için çalışmaya katılmıştır. Deney özellikle bilişsel işlevlerin yaşa bağlı düşüşlerinin etkisini en aza indirmek için tasarlanmıştır. Psikometrik ölçümlere ek olarak, öznel zamanın geçişi bir anket aracılığıyla incelenmiştir.

Bulgular: Mann Whitney U testi uygulanmıştır. Bağımlı değişkenler olarak öznel eşitlik noktası, Weber oranı ve ayrım eşiği kullanılmıştır. Genç ve yaşlı katılımcılar benzer süre ayrıştırma performansları sergilemişlerdir $(p \geq 0,05)$. Bununla birlikte, katılımcıların sözlü ifadeleri değerlendirildiğinde; yaşlı bireyler gençlere göre genellikle zamanın daha hızlı geçtiğini ve önümüzdeki bir kaç saatin daha yavaş geçeceğini beklediklerini belirtmişlerdir $(p \leq 0,05)$.

Sonuç: Bu çalışmada bilişsel taleplerin görev karmaşıklığı azaltılarak en aza indirildiği zaman, saniye üstü aralıktaki zaman algısının yaşlanma ile korunduğu gösterilmiştir.

Anahtar sözcükler: Yaşlanma; Zaman algısı 


\section{INTRODUCTION}

Interval timing requires cognitive resources such as attention, perception, and encoding of incoming temporal information; long-term memory for storage and retrieval; and comparisons with the reference temporal durations in working memory. These functions deteriorate with aging (1). Changes in time perception are reported in healthy aging $(2,3)$ as in several other neuropsychiatric disorders such as Parkinson's Disease (3). However, the extent to which these changes are attributable exclusively to time perception is debated because of the confounding factors introduced by the underlying cognitive processes. There is a vast literature on time perception models which address relevant issues regarding time perception differences in older adults. Although these are beyond the scope of our study, curious readers may find important theoretical information in (3).

A meta-analysis conducted by Block et al. (2) demonstrated that young and old groups exhibit two main differences: older adult's time judgements are less accurate and less precise (4). Studies based on a clock-speed hypothesis indicated that slowing down the internal clock of elderly causes agerelated changes in time perception $(5,6)$.

Conversely, the role of cognitive functions in the time perception of aging adults are not negligible $(7,8)$. The authors in this camp state that inaccuracy in the time judgments of old individuals stem from the reduction in cognitive functions such as working memory and attention. Various studies reported that there are high correlations between cognitive abilities and temporal judgments.

In a recent temporal bisection study, a lower sensitivity to time in older participants than in younger participants is reported; and this reduction in temporal sensitivity was explained by the deterioration of attention with aging (4).

Recently, Droit-Volet et al. (9) demonstrated that cognitive demands alter as a function of the preferred temporal task. No aging effects in temporal performance in time bisection tasks were observed in various studies $(7,10,11)$, whereas a difference emerged in other tasks. Conversely, if the complexity of the task increased, demanding more cognitive processing, the aging effects became more prominent $(2,7,8)$. Moreover, an age-related decline in attentional resources may explain some of these timing deficits (8). Although younger participants are flexible and can allocate attention to the characteristics of a task, the decline of cognitive functions may be one reason why older adults focus more on some other unrelated stimuli during the task $(7,8)$.

As indicated above, stimuli range is another crucial factor. For example, when older participants were supported by the appropriate feedback, they performed comparably to young individuals at short intervals (10). However, in studies using long intervals, older individuals exhibited a poorer performance compared to younger individuals.

Based on the above-mentioned factors, this study is designed to minimize the attentional-, motor-, and memory-related demands of the task so that the pure differences in time perception between two age groups, young and old adults, can be measured.

Previously, Akdoğan \& Balcı (12) investigated the effects of payoff manipulations on temporal bisection performance, but to the best of our knowledge, this is the first study to investigate time perception performances of Turkish adults in a time bisection task in terms of aging effects.

The main factors affecting the design:

1) The temporal task demanding the least cognitive capacities is the time bisection task (9). To minimize attentional load, the time bisection task was preferred.

2) During the task, an experimenter was in charge of pressing the appropriate button according to the verbal response of the old participants. This is preferred to minimize: a. the performance effects derived from the stress responses of old participants 
who are unfamiliar with technology, b. contribution of age-related motor deficits (13).

3) Chronometric counting derived bias is a critical issue, particularly in developmental perspective in which differences in counting ability arises (11). The best method of preventing chronometric counting is to give instructions to not count (14). Thus, before the onset of the session, each participant was told that he/she must not count.

4) A control experiment was designed to determine the visual acuity threshold of the participants and to ensure that timing performances were not affected by the visual deficiencies.

\section{MATERIALS AND METHOD}

\section{Participants}

A total of 66 volunteers participated in the study, including 33 young adults (mean age \pm SD: $25.31 \pm 3.5$ years (range 18-35), 13 F, $20 \mathrm{M}$ ) and 33 old adults (mean age \pm SD: $67.63 \pm 4.87$ years (range 60-78), 16 F, $17 \mathrm{M}$ ). For further analysis, the participants were categorized into four age groups intuitively: Young (18-25 years), middleyoung (26-35 years), young-old (60-70 years), and old-old (71-80 years), similar to (11). The participants were recruited via distributed fliers, social media and with the help of our circle of acquaintances. The participants' demographic information is presented in Table 1. This study was approved by the METU Ethics Committee. All of the participants read and signed informed consent according to the principles of the Declaration of Helsinki. All participants had normal or correctedto-normal vision and reported having no history of a neuropsychological/psychiatric disorder or alcoholism and no use of medication affecting the central nervous system.

\section{Data Collection}

\section{Procedure}

All participants were tested individually in a quiet room, either in their homes or on a university
Table 1. Demographic information of the participants.

\begin{tabular}{|l|r|r|}
\hline & Old & Young \\
\hline $\begin{array}{l}\text { Age } \\
\text { (Mean } \pm \text { SD) }\end{array}$ & $67.63 \pm 4.87$ & $25.31 \pm 3.50$ \\
\hline Gender & $\mathrm{F}=16$ & $\mathrm{~F}=13$ \\
\hline $\begin{array}{l}\text { Years of Education } \\
\text { (Mean } \pm \text { SD) }\end{array}$ & $12.38 \pm 4.80$ & $\mathrm{M}=20$ \\
\hline $\begin{array}{l}\text { SMMSE } \\
\text { (Mean } \pm \text { SD) }\end{array}$ & $26.34 \pm 0.46$ & - \\
\hline $\begin{array}{l}\text { GDS } \\
\text { (Mean } \pm \text { SD) }\end{array}$ & $5.28 \pm 0.84$ & \\
\hline
\end{tabular}

campus. They were seated in front of a PC (ASUS K55VJ-SX077D, Gpu: NVIDIA® GeForce ${ }^{\circledR}$ GT $635 \mathrm{M})$. The experimental stimuli were presented via SuperLab 4.0 software (15). The responses were recorded with a standard Qwerty keyboard.

\section{Time Bisection Task}

A red circle (6 $\mathrm{cm}$ diameter) was displayed in the center of the computer screen on a white background. The short and long anchor durations were 1.25 and $2.5 \mathrm{~s}$, respectively, and the probe durations were 1.25, 1.458, 1.667, 1.875, 2.083, 2.292 , and $2.5 \mathrm{~s}$. The experimenter pressed the appropriate button according to the participant's verbal response indicating a binary time judgement (short or long) related to the appearance of the red circle. A 500 ms feedback was presented after each short and long anchor duration. Feedback was provided for correct and incorrect responses in the form of tick and cross pictures, respectively.

A session included three phases: Pre-training, training, and testing. In the pre-training phase, the two anchor durations were presented in sequence: Three short and three long anchor durations. The experimenter introduced the durations by saying "This circle appears on the screen for a short/long time.", and no response was expected from the 
participant. In the training phase, the participants learned to respond by pressing " $\mathrm{S}$ " for short and "L" for long durations. Two blocks of 10 trials, each including five short and five long stimuli, were introduced. Appropriate feedback was given after each response. The inter-trial interval varied between 0.5 and $2 \mathrm{~s}$ (4). If more than $70 \%$ of the participant's responses were correct in the second phase, the testing phase was presented (4). The same procedure used for training was used in the testing phase with the addition of probe durations, but feedback was given only for the shortest and longest durations. The testing phase was composed of 10 blocks of seven trials each (70 testing trials): There was one trial for each $\mathrm{S}$ and $L$ anchor and the five intermediate durations. The presentation of these trials was randomized in each block. The task design is presented in Figure 1.

\section{Visual Acuity Task}

The red circle used in the time bisection experiment was modified by adding various levels of transparency. In total, 29 stimuli were created in MATLAB with varying transparency levels $(0.004$ (mostly transparent), 0.008, 0.012, .., 0.40, 0.70, 1 (opaque)). Each stimulus was displayed for 1.25 $\mathrm{s}$ and then the participant was asked to decide whether they saw a colorful circle. If the answer was "yes," they were told to press "+"; otherwise, they were told to press "-"; no feedback was given. Each participant completed five blocks of 29 randomized trials.

\section{Questionnaires}

The participants were asked to complete a questionnaire entitled, "Speed of Time" (16). The items given below were rated with a five-point scale.

1. How fast does time usually pass for you?

2. How fast do you expect the next hour to pass?

3. How fast did the previous week pass for you?

4. How fast did the previous month pass for you?

5. How fast did the previous year pass for you?

6. How fast did the previous 10 years pass for you?

Figure 1. Time bisection task design. a. Pre-training phase, b. Training phase: 2 blocks with 10 trials, c. Testing phase: 10 blocks with 7 trials. *Feedbacks in the testing phase were given only for the anchor durations (1.25 and $2.5 \mathrm{~s}$ ).

a.

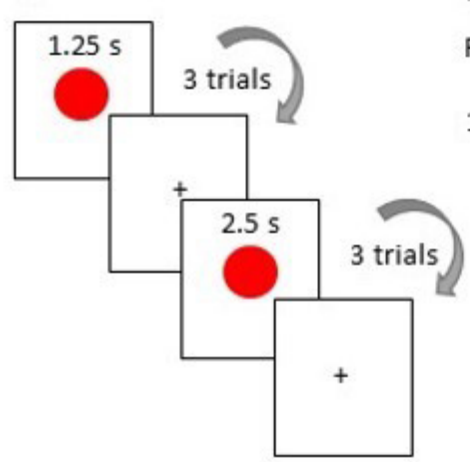

b.

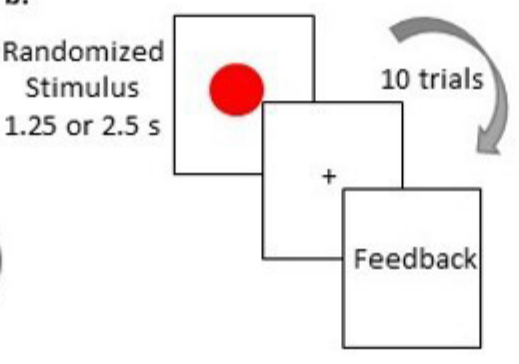

c.

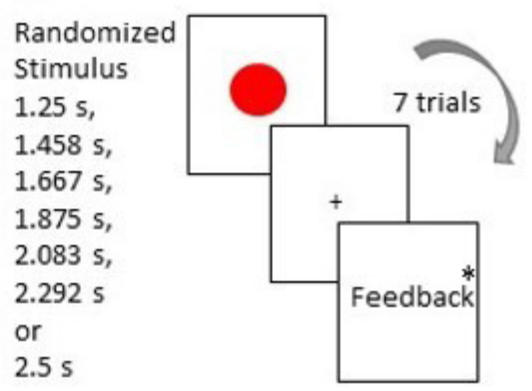


To determine whether the older participants were cognitively healthy, the Standardized Mini Mental State Examination (SMMSE) (17) and Geriatric Depression Scale (18) were administered. The cut-off scores were 25 and 11, respectively. All participants fulfilled these criteria, as indicated in Table 1.

\section{Measurements}

The bisection point (BP) is defined as the stimulus duration which is evaluated as short or long with equal probability. By investigating the curve-fitted data of each participant, the signal duration corresponding to $50 \%$ of the long responses (i.e., $\mathrm{p}($ long $)=0.5$ ) was calculated and reported as the BP. The difference limen (DL) is a measure of variability calculated by subtracting the stimulus duration corresponding to $25 \%$ of responses evaluated as "long" from the stimulus duration at which $75 \%$ of the responses were evaluated as "long" and then divided by 2. A larger DL corresponds to a lower sensitivity and vice versa. The Weber ratio (WR) is defined as the relative temporal sensitivity and is calculated by dividing the DL by the BP. A lower WR is reflective of greater sensitivity to time.

\section{RESULTS}

\section{Time Bisection}

The probability of the long responses is plotted against the stimulus duration as presented in Figure 2. For further analysis, the BP, WR, and DL were calculated by fitting a logarithmic function to the psychophysical functions from individuals in MATLAB via psignifit 4 software (19). One young participant (insufficient fit) and one old participant (failure to reach the $70 \%$ success criterion in the second training block) were excluded from the study.

Outliers were checked by using z-scores with a threshold set at 3.29 (20). There was no z-score greater than 3.29, so no data was excluded.
Data was non-normally distributed, the MannWhitney $U$ test indicated that the BP of the young participants ( $M d n=1.885)$ did not differ significantly from that of the old subjects $(\mathrm{Mdn}=$ 1.873, $U=553, z=0.551, n s)$. Additionally, the WR of the young participants $(\mathrm{Mdn}=0.098) \mathrm{did}$ not differ significantly from that of the old subjects (Mdn $=0.0984, U=524, z=0.161$, ns). Similarly, the DL of the young participants $(M d n=0.196)$ did not differ significantly from that of the old subjects $(\mathrm{Mdn}=0.183, \mathrm{U}=534.5, \mathrm{z}=0.302, \mathrm{~ns})$. Table 2 demonstrates the outcomes of the time bisection experiment.

Table 2. Time bisection experiment outcomes (median \pm SD).

\begin{tabular}{|l|r|r|}
\hline & Old & Young \\
\hline BP & $1.867 \pm 0.032$ & $1.881 \pm 0.020$ \\
\hline WR & $0.107 \pm 0.008$ & $0.109 \pm 0.008$ \\
\hline DL & $0.198 \pm 0.014$ & $0.206 \pm 0.016$ \\
\hline
\end{tabular}

BP: Bisection Point; WR: Weber Ratio; DL: Difference Limen

Figure 2. Proportion of long responses versus stimulus duration.

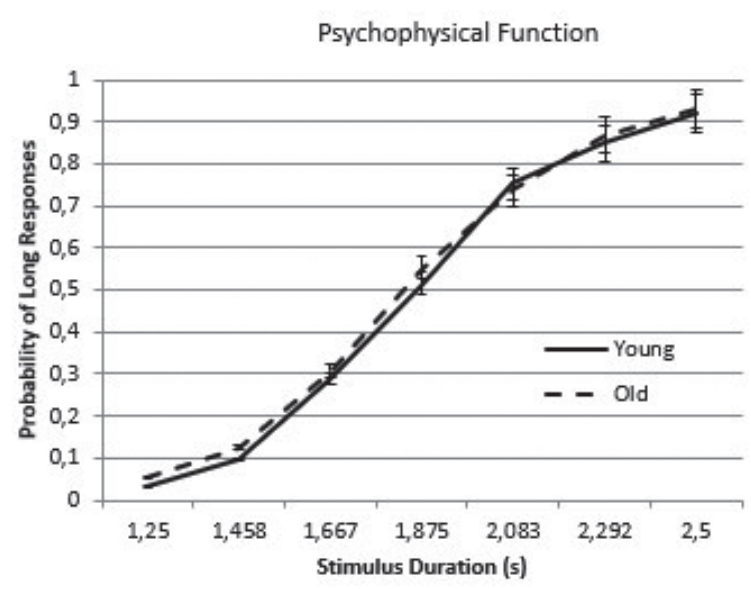


None of the variables exhibited significant effects of aging through four age categories. MannWhitney $U$ test showed that years of education of young participants $(M=18.47, S D=0.504)$ were significantly higher than old ones $(M=12.38$, $S D=0.84), U=60.5, z=-6.073 p \leq .001$. This might have affected time bisection performance but, the correlation analyses indicated that there was no relationship between education levels and $B P, W R$ and $\mathrm{DL}$. Also, a regression analysis was conducted to investigate the effect of age and education together on $\mathrm{BP}, \mathrm{WR}$, and $\mathrm{DL}$ which indicated insignificant relationship among them.

\section{Visual Acuity Task}

Psychometric functions were calculated for each subject, and a logarithmic function was fitted. The probability of saying yes was plotted against the stimulus range. BP was calculated on curvefitted data, and this value was defined as the visual acuity threshold. Since the data were nonnormally distributed, the Mann-Whitney $U$ test was conducted. The visual acuity threshold of the young participants ( $\mathrm{Mdn}=0.0256)$ did not differ significantly from that of the old participants ( $\mathrm{Mdn}$ $=0.0297, U=397, z=-1.544, n s)$. This was also replicated in the four age categories. There was no age effect on visual acuity threshold, which indicates that the young and old participants' vision did not differ.

Figure 3. Mean ratings of the young and old adults on items 1-6 of the speed of time questionnaire. The scores represent time passing: Very slowly $[-2]$, slowly $[-1]$, neither fast nor slow [0], fast [1], and very fast [2].

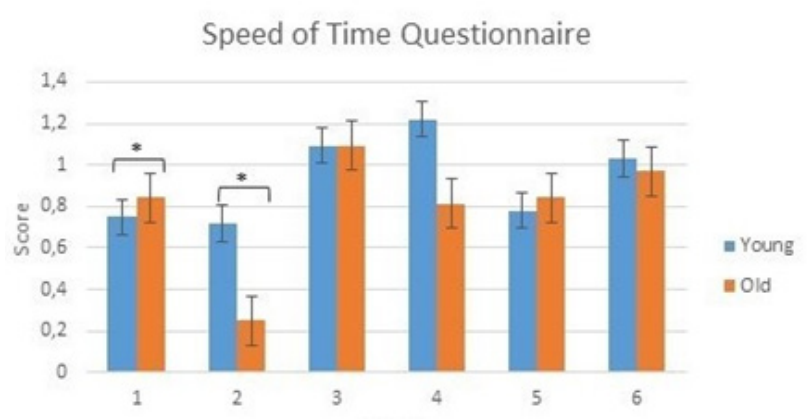

\section{The Speed of Time Questionnaire}

An independent samples median test showed that there was a significant trend of higher scores in item 2 for young subjects $(\mathrm{Mdn}=1)$ than for old subjects ( $M d n=0, \chi 2=7.570, p \leq 0.01$ ).

When the items were compared according to the four age groups, the independent samples median test demonstrated a significant difference among young $(\mathrm{Mdn}=1)$, middle-young $(\mathrm{Mdn}=$ $1)$, young-old $(M d n=1)$, and old-old $(M d n=1)$ age groups for item 1 ( $\chi 2=10.353, p \leq 0.05$ ) (Bonferroni corrected). Item 2 was also rated as significantly different among the young ( $\mathrm{Mdn}=$ $1)$, middle-young $(M d n=1)$, young-old $(M d n=0)$, and old-old (Mdn $=0)$ age groups ( $\chi 2=9.339, \mathrm{p}$ $\leq 0.05$ ) (Bonferroni corrected).

The factorability of six items was examined using Principal Component Analysis and a rotation method of Varimax with Kaiser Normalization. The sampling adequacy was verified with the KaiserMeyer-Olkin measure, $\mathrm{KMO}=.646$. According to Bartlett's test of sphericity $\chi 2(15)=60.499$, $\mathrm{p} \leq .001$, correlations between variables were sufficiently large for PCA. Overall analyses yielded two factors: Item 1 and 2 constituted a factor related to present time perception. The other four items regarding past time information formed a second factor. Two components had eigenvalues over than Kaiser's criterion of 1 and they jointly explained $56.05 \%$ of the variance. Furthermore, the reliability of the questionnaire is verified (the value of Cronbach's alpha $=0.668$ ).

\section{DISCUSSION}

Although a decline is reported in various studies $(5,8)$ in sensitivity to time in elderly, such a difference in the time bisection task was not observed in this study. The BP, WR, and DL were similar between the two age groups. In this study, the BP finding in previous studies $(7,8,10,11)$ is replicated.

The strict control of our task design in terms of 
cognitive demands might be a reason. The possible effects of cognitive decline observed in aging were minimized by the choice of a less complex task in terms of how time is reported as well as how motor responses are collected. Additionally, an experimenter recorded the old participants' responses to eliminate the likely effects of agerelated motor deficits on task performance.

The similar timing performance of the two age groups may stem from compensation strategies. Previously, it was demonstrated that healthy elderly frequently realize their cognitive deficits, and a significant correlation between timing performance and the awareness of susceptibility to time distortion is reported (21). If the participants were more aware of their deficit, their temporal judgments were more accurate and precise. Moreover, the authors clarified that the older participants used compensation to improve their performance such that more attentional resources were allocated to the temporal task. This outcome can be interpreted as follows: The elderly in this study might have used compensation strategies. On another front, it was shown that education levels of the young and old participants differ. Although it might be a candidate factor affecting temporal judgements, correlation and regression analyses showed that there was no relationship between education levels and BP, WR and DL. Hence an interference due to education levels cannot be a contributing factor to the results.

There was a difference in the self-rated reports of time perception between the young and old participants. For item 1, which measures how fast time passes for the individual, the older participants' scores were higher than their younger counterparts. This might reveal a folk theory about aging and time perception. Older adults are influenced by a general belief that "time appears to pass more quickly as people grow older." The ratings of item 2 reveal that older participants expect the next hour to pass slower. This expectation might be a result of the older participants believing that the next hour, in which the experiment would be conducted, would be challenging for them. Our results did not support those obtained by Wittmann and Lehnhoff (16), who found a significant age-related effect only in item 6 of this questionnaire.

Finally, the effects of the environmental setting must be addressed. There is a discrepancy between the experimental environment and real life, which leads to differences between attentional demands. The internal clock of older adults shows a larger discrepancy between the lab environment and daily life since they are more susceptible to distractions than younger adults (5). Older adults' internal clocks may run faster during the experiment than in daily life.

\section{CONCLUSION}

Through this study, it is demonstrated that the perception of time in the supra-second range is preserved with aging when cognitive demands are minimized by reducing task complexity. Only psychometric measurements were used in this study; additional neuropsychology test batteries are imperative for detailed assessment of the cognitive states of the participants. Additional research is necessary to unveil the time perception and interval timing behavior of older participants at other time interval scales.

\section{ACKNOWLEDGEMENTS}

This study was supported in part by Düzce University. We are grateful to the trainee students Ece Dinçer and Illayda Çalışkan for their assistance during data collection. We also thank Assoc. Prof. Annette Hohenberger, who inspired this study. We appreciate the contributions of Prof. Sami Gülgöz and Dr. Merve Eriş Hasırcı during the translation of Speed of Time Questionnaire.

\section{CONFLICT OF INTEREST}

The authors state that they have no conflict of interest. 


\section{REFERENCES}

1. Harada CN, Natelson Love MC, Triebel K. Normal cognitive aging. Clin Geriatr Med. 2013;29(4):737752. (PMID: 24094294)

2. Block RA, Zakay D, Hancock PA. Human aging and duration judgments: A meta-analytic review. Psychol Aging. 1998;13(4):584-596. (PMID: 9883459)

3. Balci F, Meck WH, Moore $H$, and Brunner D. Timing Deficits in Aging and Neuropathology. In: Bizon, Jennifer L., Woods, Alisa G. (Eds). Animal Models of Human Cognitive Aging. Humana Press 2009, pp $1-41$.

4. Lamotte M, Droit-Volet S. Aging and Time Perception for Short and Long Durations: A Question of Attention? Timing Time Percept. 2017, 5(2):149-167.

5. C Lustig. Grandfather's Clock: Attention and Interval Timing in Older Adults, In: Meck W (Eds). Functional and neural mechanisms of interval timing, Boca Raton, FI CRC 2003, pp 261-293.

6. Craick F A, Salthouse T A (Eds). The handbook of aging and cognition. Psychology press, 2000, pp 3336.

7. Lustig $\mathrm{C}$, Meck WH. Modality differences in timing and temporal memory throughout the lifespan. Brain Cogn. 2011;77(2):298-303. (PMID: 21843912)

8. Lustig $C$, Meck WH. Paying attention to time as one gets older. Psychol Sci. 2001; 12(6), 478-484. (PMID: 11760135)

9. Droit-Volet S, Wearden JH, Zélanti PS. Cognitive abilities required in time judgment depending on the temporal tasks used: A comparison of children and adults. Q J Exp Psychol. 2015; 68(11): 2216-2242. (PMID: 25730557)

10. Wearden $\mathrm{JH}$, Wearden AJ, Rabbitt PMA. Age and IQ Effects on Stimulus and Response Timing. J Exp Psychol Hum Percept Perform. 1997;23(4):962-979.

11. McCormack T, Brown GD, Maylor EA, Darby RJ, Green D. Developmental changes in time estimation: comparing childhood and old age. Dev Psychol. 1999;35(4):1143-1155. (PMID: 10442882)

12. Akdoğan $B, B a l c ı F$. The effects of payoff manipulations on temporal bisection performance. Acta Psychol. 2016;170:74-83.
13. N Charness, M C Fox, and A. L Mitchum. Life-span cognition and information technology, In: Karen I. Fingerman, Cytnhia A. Berg, Jacqui Smith and Toni C. Antonucci (Eds). Handbook of life-span development. New York, Springer Publishing Company. 2011, pp. 331-361.

14. Rattat AC, Droit-Volet S. What is the best and easiest method of preventing counting in different temporal tasks? Behav Res Methods. 2012;44(1):67-80. (PMID: 21789731)

15. Haxby JV, Lalonde FF, Parasuraman R, Abboud H. SuperLab: General-purpose Macintosh software for human experimental psychology and psychological testing. Behav Res Methods, Instruments, Comput. 1993;25(3):400-405.

16. Wittmann M, Lehnhoff S. Age Effects in Perception of Time. Psychol. Rep. 2005;97(7):921-935. (PMID: 16512313)

17. Güngen C, Ertan T, Eker E, Yaşar R, Engin F. Reliability and validity of the standardized Mini Mental State Examination in the diagnosis of mild dementia in Turkish population. Turk J Psychiatry 2002;13(4):273281. (PMID:12794644) (in Turkish).

18. Ertan $T$ and Eker E. Reliability, validity, and factor structure of the geriatric depression scale in Turkish elderly: Are there different factor structures for different cultures? Int. Psychogeriatrics 2000;12(2):163172. (PMID: 10937537)

19. Schütt HH, Harmeling $\mathrm{S}$, Macke JH, Wichmann FA. Painfree and accurate Bayesian estimation of psychometric functions for (potentially) overdispersed data. Vision Res. 2016; 122: 105-123.

20. Raykov T, Marcoulides GA. An introduction to applied multivariate analysis: Routledge.2012,pp 65.

21. Lamotte M, Izaute M, Droit-Volet S. Awareness of time distortions and its relation with time judgment: A metacognitive approach. Conscious Cogn. 2012;21(2):835-842. 